\title{
Length-weight relationship of trahira Hoplias aff. malabaricus (Bloch, 1794) in a regulated stream of southern Brazil
}

\author{
Fabiano Corrêa ${ }^{1 *}$ \\ Edson Fontes De Oliveira ${ }^{2}$ \\ Juvêncio Pouey ${ }^{1}$ \\ Sérgio Piedras ${ }^{1}$ \\ ${ }^{1}$ Laboratory of Ichthyology, Federal University of Pelotas, Pelotas - RS, Brazil \\ Laboratório de Ictiologia, Universidade Federal de Pelotas, Campus Capão do Leão \\ CEP 96160-000, Pelotas - RS, Brasil \\ ${ }^{2}$ Laboratory of Theoretical and Applied Ecology \\ Federal Technological University of Paraná, Londrina - PR, Brazil \\ * Corresponding author \\ correafecologia@yahoo.com.br
}

Submetido em 02/03/2015

Aceito para publicação em 22/12/2015

\section{Resumo}

Relação peso-comprimento da traíra Hoplias aff. malabaricus (Bloch, 1794) em um arroio regulado no sul do Brasil. Este trabalho apresenta um estudo alométrico da relação peso-comprimento de Hoplias aff. malabaricus coletados no reservatório e no Arroio Chasqueiro, sul do Brasil. Foram coletados 112 espécimes com comprimento total entre 124 e $386 \mathrm{~mm}$. Os parâmetros estimados do modelo comprimento-peso foram estatisticamente significativos e mostraram um crescimento alométrico positivo para a espécie.

Palavras chave: Alometria; Lagoa Mirim; Pesca; Região neotropical

\section{Abstract}

This paper presents an allometric study of the length-weight relationship of Hoplias aff. malabaricus collected in the Chasqueiro Reservoir and Stream in southern Brazil. During the study, 112 specimens were collected with total lengths ranging from 124 to $386 \mathrm{~mm}$. The estimated parameters of the length-weight model were statistically significant and showed positive allometric growth for this species.

Key words: Allometry; Fishery; Mirim Lagoon; Neotropical region 
Studies of fish populations related to trophic ecology, reproduction, and estimates of growth parameters are very important because they generate information needed to understand ecological relationships and this contributes to the management of fish stocks. Estimates of the length-weight relationship of a species provide relevant information for fishery management and conservation, as well as estimate the growth pattern of a species (LE CREN, 1951; FROESE, 2006; CHU et al., 2012; ANTONETTI et al., 2014). According to Froese (2006), there are few published studies about lengthweight relationships and these are only for a limited number of species, especially marine species, which makes modeling aquatic ecosystems more complicated.

Hoplias aff. malabaricus (Bloch, 1874), popularly known as trahira, has a wide distribution in freshwater aquatic ecosystems in South and Central America, and is found in rivers, streams, wetlands, lakes, lagoons, and reservoirs (REIS et al., 2003). It is a piscivorous species that has an important role in the structure of food webs; the young have a diet based on insects and the adults consume fish (CORRÊA et al., 2012). The species reproduces mainly during periods of higher temperatures; females lay their eggs in vegetation and parental care is performed by males (BEMVENUTI; MORESCO, 2005). Studies that estimate the growth model of $H$. aff. malabaricus have been conducted in other regions of Brazil (BARBIERI, 1989; CHAVES et al., 2009; NOVAES; CARVALHO, 2011); however, in the state of Rio Grande do Sul there are few studies about this species in regards to the hydrographic of Mirim Lagoon system.

The trahira plays an important economic role for fishermen from the Mirim Lagoon system (PIEDRAS et al., 2012), so it is essential to conserve the species in this region. Mitigation measures for the conservation of the species include, for example, subsidizing information that should be recorded for the conservation of this important species in the system. This study provides the length-weight relationship of $H$. aff. malabaricus in a hydrographic basin of the Mirim Lagoon system in southern Brazil. The hydrographic basin of the Chasqueiro Stream (BHAC) is located in the city of Arroio Grande (31 6'51'S/505'17'W) (Figure 1) (CORRÊA et al., 2015b). The region has a humid subtropical climate, described by the Köppen-Geiger climate classification as $\mathrm{Cfa}$, with an average annual rainfall ranging from 1,200 to $1,450 \mathrm{~mm}$ and monthly

FIGURE 1: Area of study: (A) Southern Brazil with delimitation of Mirim Lagoon system, between Brazil and Uruguay (A); localization of hydrographic basin Chasqueiro stream (circle) (B); and (C) Pictures of the sample points: 1 and 2 (upstream), 3 and 4 (downstream), 5 and 6 (reservoir).

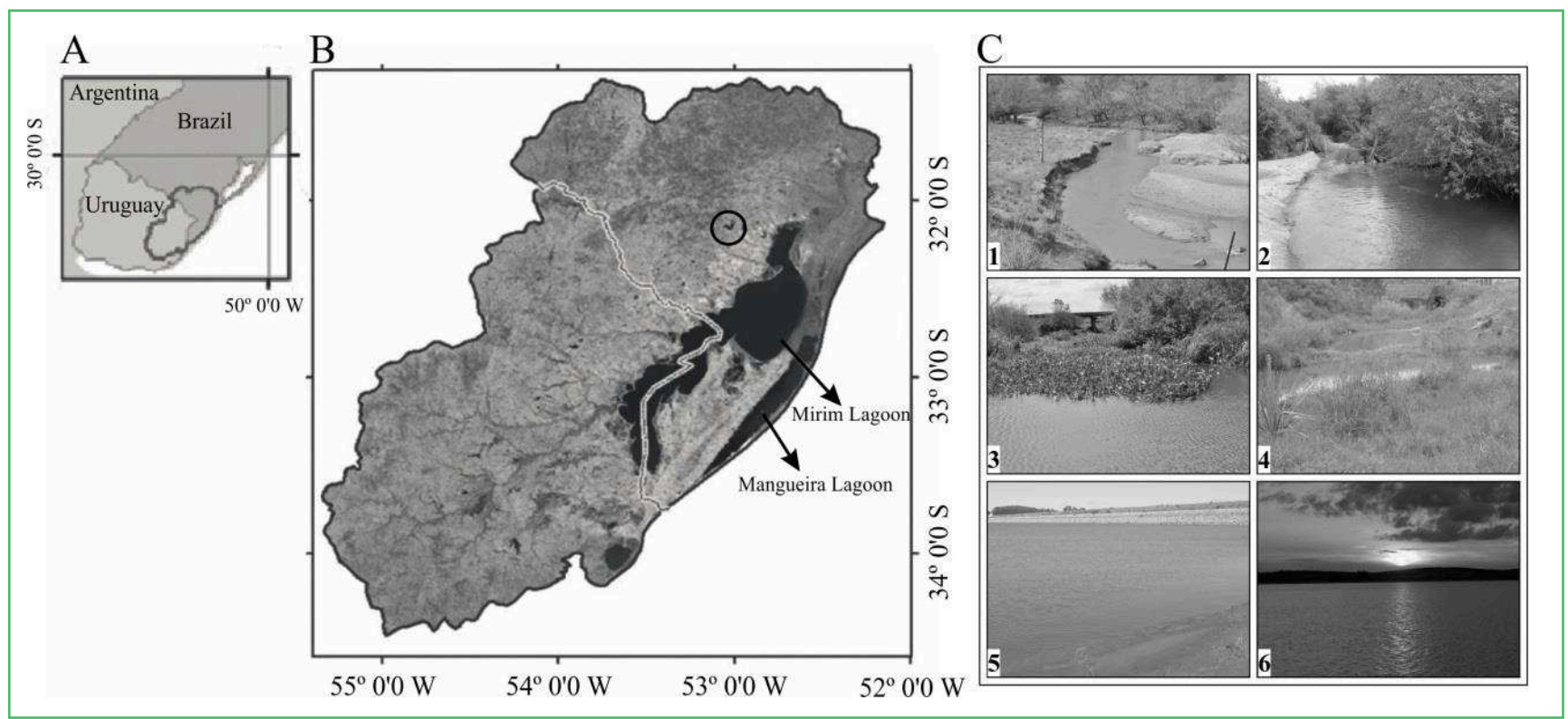


average temperatures of $25^{\circ} \mathrm{C}$ during the hottest months and $11{ }^{\circ} \mathrm{C}$ during the coldest months. The BHAC is formed by two main streams, the upstream area of the Chasqueiro Reservoir is $248.42 \mathrm{~km}^{2}$ and is formed by two main tributaries, the Chasqueiro Stream with 114.84 $\mathrm{km}^{2}$ and the Chasqueirinho Stream with $133.58 \mathrm{~km}^{2}$ (CORRÊA et al., 2015b).

The Chasqueiro Reservoir has a surface area of 1,800 ha and is used primarily to irrigate rice fields (SONDOTÉCNICA, 1976; CORRÊA et al., 2014; 2015a). The specimens were collected from the following six points: 1 and 2 (upstream), 3 and 4 (downstream), and 5 and 6 (reservoir) (Figure 1). Fish were collected monthly for a one-year period between the months of August 2012 to July 2013 (SISBIO n. 34389-1). To collect the specimens, the following was used: a) gill net, $75 \mathrm{~m}$ long with 10, 20, 30, 40 and $50 \mathrm{~mm}$ mesh (knot to knot), submerged for a period of $24 \mathrm{~h}$ and checked after $12 \mathrm{~h}$, which were used at reservoir depths between 1.0 and $2.5 \mathrm{~m}$ to capture larger individuals (>200 mm); b) trawl net, $5 \mathrm{~m}$ long, 2.25 high, with $5 \mathrm{~mm}$ mesh (knot to knot), used in the coastal zones of the reservoir and downstream, with five trawls at each site per collection; c) landing net, $5 \mathrm{~mm}$ mesh opening, $35 \mathrm{~cm}$ wide, and 50 $\mathrm{cm}$ long, used upstream and downstream, in areas with and without vegetation, for 30 minutes at each site at depths ranging from $10 \mathrm{~cm}$ to one meter. The collected fish were stored in labeled, plastic bags, and fixed in $10 \%$ formalin, then taken to the laboratory where they were transferred to $70 \%$ alcohol.

After each sample was taken, the specimens were transferred to the Laboratory of Ichthyology, at the Federal University of Pelotas (UFPeL), where they were measured for total weight $(W)$ in grams $(\mathrm{g})$ and total length $(L)$ in millimeters $(\mathrm{mm})$, and the standard error (SE) was calculated. The parameters $(a)$ and $(b)$ were estimated by linear regression expressed by the equation $\log (W)=\log (a)+b \log (L)$; extreme values were excluded from the analysis (FROESE, 2006), and for the adjusted model the statistical software PAST 3.0 (PAlaeontological STatistics, HAMMER et al., 2013) was used. Where $W$ is the total weight of fish $(\mathrm{g}), a$ is the coefficient related to body shape, $L$ is the total length $(\mathrm{mm})$, and $b$ is an exponent that is related to the growth of fish (isometric or allometric) (FROESE, 2006). The data was analyzed together because the number of captured specimens was not similar between different biotopes, and possible differences among the average size of the fish captured downstream and from the reservoir were evaluated by the non-parametric MannWhitney test (with Monte Carlo resampling 10,000 "replication", $n=90$ and 22 for downstream and the reservoir, respectively) with the statistical package PAST 3.0 (HAMMER et al., 2013). Voucher specimens were deposited in the Ichthyological Collection of the Federal University of Rio Grande (\#ICFURG-0029).

During the study, 112 specimens were collected with a total average length of $170.3 \pm 6.3 \mathrm{~mm}$ and a total average weight of $97.6 \pm 14.1 \mathrm{~g}$. The 22 individuals captured in the reservoir had an average total length of $255.7 \pm 18.1 \mathrm{~mm}$ and an average total weight of $284.4 \pm$ $54.4 \mathrm{~g}$. Downstream, 90 individuals were collected with an average length of $150.4 \pm 4.2 \mathrm{~mm}$ and an average weight of $51.9 \pm 4.5 \mathrm{~g}$. When comparing the average length of individuals between biotopes, we observed a significant difference ( $p=0.001)$. During the study, the abundance of Hoplias aff. malabaricus was lower in the reservoir $(n=22)$ (limnetic zone); however, these individuals had a significantly higher mean length $(p=0.001)$ than individuals that were captured downstream (shallow zone) (Figure 2). The parameter of length-weight relationship estimated was statistically significant $\left(p=0.001, R^{2}=0.98\right)$ and the linear regression showed a value of $b=3.11\left(W=0.0000148 * L^{3.11}\right)$ (Figure 3).

More trahira were captured downstream compared with the reservoir. This may be associated with the environmental structure in the downstream area, for example, in this region there are aquatic macrophytes, which favors fish reproduction and feeding (THOMAZ; CUNHA, 2010). In addition, the downstream environment has a smaller area compared to the reservoir. According to Hermes-Silva and Zaniboni (2012), the presence of macrophytes provides different microhabitats that act as a refuge from predators as well as feeding sites. It is worth noting that gillnets were not used downstream because it is a wading area habitat. Indeed, the larger 
FIGURE 2: Number of individuals (A) and average total length $(\mathrm{mm} \pm \mathrm{SE})(\mathrm{B})$ of individuals captured by biotope, hydrographic basin of Chasqueiro stream, Arroio Grande city, Rio Grande do Sul state, Brazil.

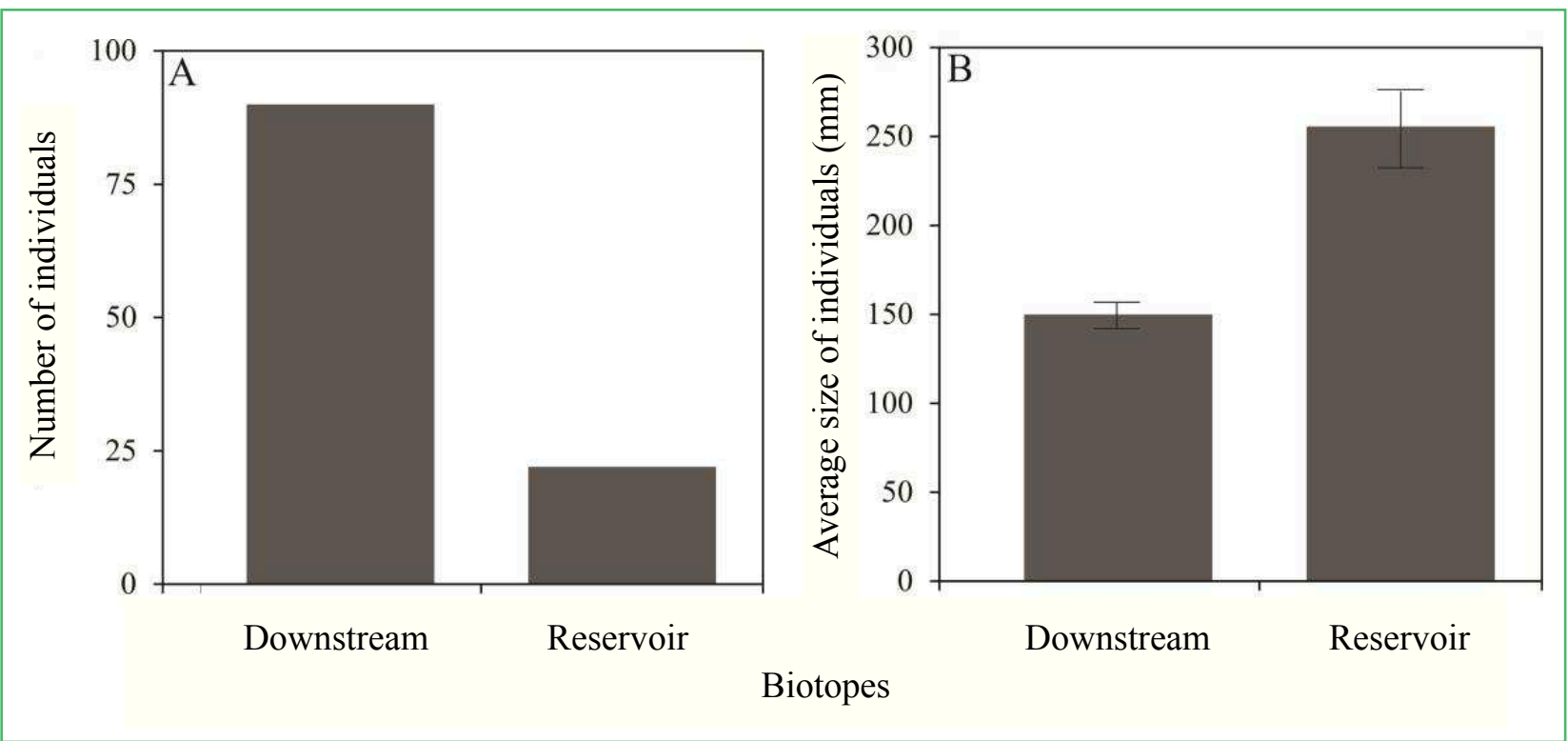

FIGURE 3: Model linear regression for length-weight relationship of Hoplias aff. malabaricus, in the Chasqueiro stream, Arroio Grande city, Rio Grande do Sul state, Brazil.

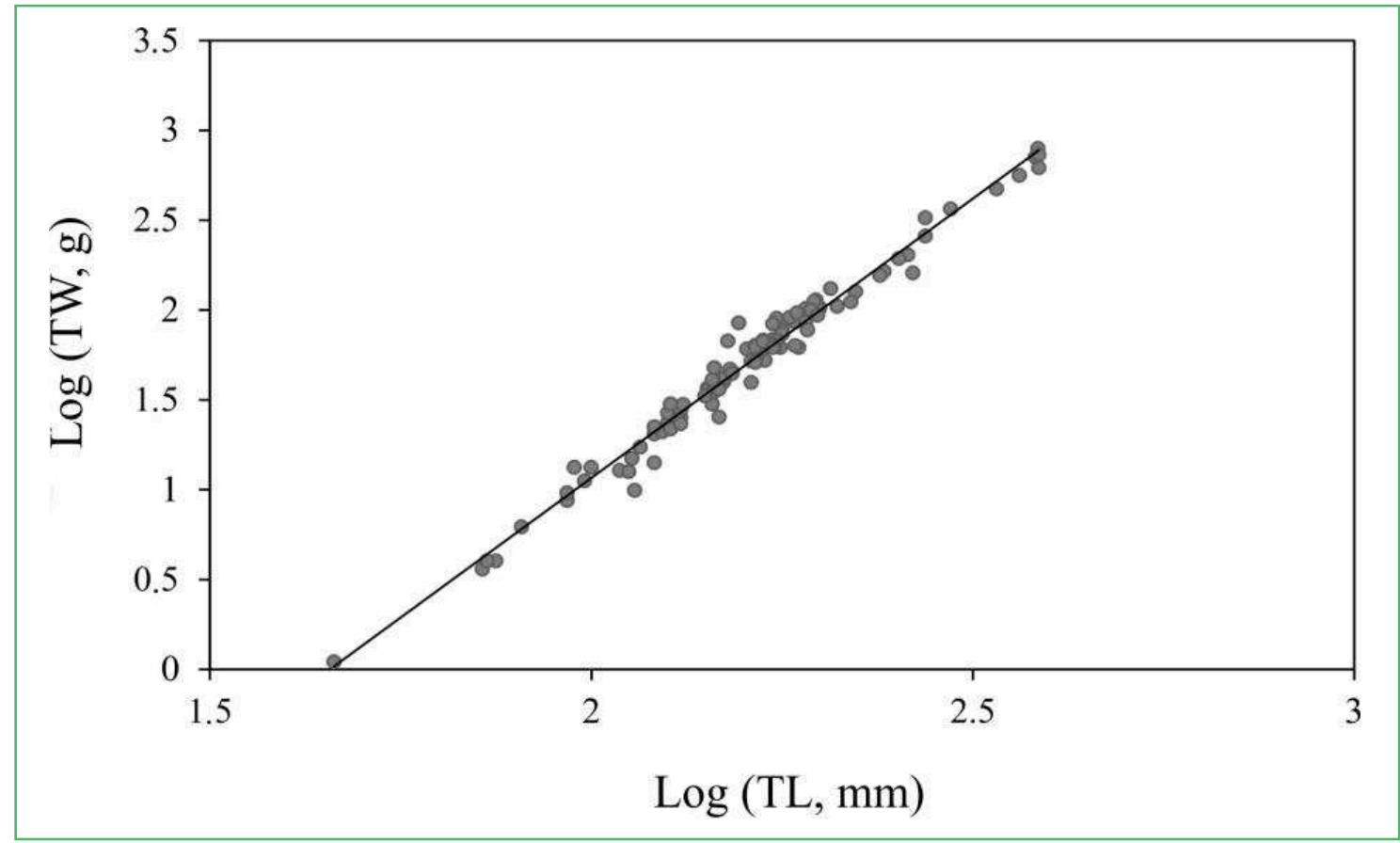


individuals that were captured in the reservoir may be associated with the type of sampling devices used for this biotype because gillnets tend to be more size selective, capturing larger fish in deeper areas. This pattern is described by other authors, such as Artioli et al. (2009) that studied the structure of the fish assemblage in Mangueira Lagoon in southern Brazil. These authors noted that in shallow areas the dominant species are small fish, such as minnows, while deeper areas are dominated by larger species, such as $H$. aff. malabaricus. Similar patterns were also observed by Garcia et al. (2006) and Ceni and Vieira (2013).

The data obtained from the regression values $(b)$ for $H$. aff. malabaricus in BHAC indicate a positive allometric growth, showing an ontogenetic pattern where species increase their body mass along with their length. A comparison of allometric growth for $H$. aff. malabaricus is presented below. Chaves et al. (2009), when studying the species in northeastern Brazil, recorded a lower value of $b$ for January and February $(\mathrm{n}=27, b=2.25)$ that indicated negative allometric growth, and a higher value of $b$ for May and June (n $=22, b=3.20)$ that indicated positive allometric growth; these values can be associated with the sample size, type of environment and seasonal variation. Lower values were also found by Mello et al. (2009) in the Santa Luiza River, in Uruguay ( $\mathrm{n}=22, b=2.97)$. Novaes and Carvalho (2011) studied the population structure of trahira in the Jurumirim Reservoir, Brazil, and found negative allometric growth for $b(\mathrm{n}=426, b=2.75)$ that indicated the species grows more slowly in terms of weight than length, which differs from the type of growth of trahiras in the BHAC. Antonetti et al. (2014) described a similar value $(\mathrm{n}=57, b=3.09)$ compared to BHAC individuals, indicating positive allometric growth. Barbieri et al. (1982) and Barbieri (1989) studied Hoplias aff. malabaricus in two reservoirs in Brazil, the Lobo and Manjolinho ( $b=3.0$ and 3.2, respectively).

According to Araújo and Vicentini (2001), values lower than 3 indicate that individuals become more longilineal during growth and values higher than 3 indicate that individuals become rounder. $\mathrm{Chu}$ et al. (2012) indicate that the value of $b$ for the length-weight ratio can be used as a biological attribute, which may be related to predation as well as growth. In this context, ontogenetic changes in fish lead to changes in feeding ecology where the fish adapt to consume the diversity of food items available in the ecosystem (MAZZONI; COSTA, 2007; CORRÊA et al., 2012). In conclusion, $H$. aff. malabaricus demonstrated positive allometric growth in the study site. Furthermore, future studies related to feeding ecology, reproductive, age and growth, as well as continuous monitoring of the fish stocks in the region, would generate more detailed information that could aid in the preservation of these fish in the hydrographic system of the Mirim Lagoon and adjacent areas. Mitigation measures should be taken for the conservation of this species because it is a top predator and its decline may create disturbances in the fish community.

\section{Acknowledgments}

We are grateful to Thiago Tuchtenhagen and Aline Luçardo by assistance in the collection and triage, SISBIO (\# 34389-1), Mirim Lagoon Agency (ALG) and CAPES financial aid.

\section{References}

ANTONETTI, D. A.; LEAL, M. E.; SCHULZ, U. H. Length-weight relationships for 19 fish species from the Jacuí Delta, RS, Brazil. Journal Applied Ichthyology, Kiel, v. 30, p. 259-260, 2014.

ARAÚJO, F. G.; VICENTINI, R. N. Relação peso-comprimento da corvina Micropogonias furnieri (Desmarest) (Pisces, Sciaenidae) na Baía de Sepetiba, Rio de Janeiro. Revista Brasileira de Zoologia, Curitiba, v. 18, n. 1, p. 133-138, 2001.

ARTIOLI, L. G. S.; VIEIRA, J. P.; GARCIA, A. M.; BEMVENUTI, M. A. Distribuição, dominância e estrutura de tamanhos da assembleia de peixes da lagoa Mangueira, sul do Brasil. Iheringia, Porto Alegre, v. 99, p. 409-418, 2009.

BARBIERI, G. Dinâmica da reprodução e crescimento de Hoplias malabaricus (Bloch, 1794) (Osteichthyes, Erytrhinidae) da Represa do Monjolinho, São Paulo. Revista Brasileira de Zoologia, Curitiba, v. 6, n. 2, p. 225-233, 1989.

BARBIERI, G.; VERANI, J. R.; BARBIERI, M. C. Dinâmica quantitativa da nutrição de Hoplias malabaricus (Bloch, 1874) na represa do Lobo (Brotas-Itirapina, São Paulo) (Pisces,Erythrinidae). Revista Brasileira de Biologia, São Carlos, v. 42, n. 2, p. 295-302, 1982.

BEMVENUTI, M. A.; MORESCO, A. Peixes - Áreas de banhados e lagoas costeiras do extremo sul do Brasil. v. 1. Porto Alegre: Associação Brasileira de Recursos Hídricos, 2005. 63 p. 
CENI, G.; VIEIRA, J. P. Looking through a dirty glass: how different can the characterization of a fish fauna be when distinct nets are used for sampling? Zoologia, Curitiba, v. 30, p. 499-505, 2013

CHAVES, M. F.; TORELLI, J.; TARGINO, C. H.; CRISPIM, M. C. Dinâmica reprodutiva e estrutura populacional de Hoplias aff. malabaricus (Bloch, 1794) (Characiformes, Erythrinidae), em açude da Bacia do Rio Taperoá, Paraíba. Biotemas, Florianópolis, v. 22 , p. $85-89,2009$

CHU, W. S.; HOU, Y. Y.; UENG, Y. T.; WANG, J. P. Correlation between the length and weight of Arius maculatus off the southwestern coast of Taiwan. Brazilian Archives of Biology and Technology, Curitiba, v. 55, n. 5, p. 705-708, 2012.

CORRÊA, F.; CLAUDINO, M. C.; BASTOS, R. F.; HUCKEMBECK, S.; GARCIA, A. M. Feeding ecology and prey preferences of a piscivorous fish, in the Lagoa do Peixe National Park, a Biosphere Reserve in Southern Brazil. Environmental Biology of Fishes, New York, v. 93, p. 1-12, 2012.

CORRÊA, F.; OLIVEIRA, E. F.; POUEY, J.; PIEDRAS, S. R. N. Length-weight relationships of 18 fish species from Siluriformes order, in one hydrographic basin subtropical, southern Brazil. Journal of Applied Ichthyology, Kiel, v. 31, n. 5, p. 1-3, 2015 a.

CORRÊA, F.; OLIVEIRA, E. F.; TUCHTENHAGEN, T.; POUEY, J.; PIEDRAS, S. R. N. Ichthyofauna of the hydrographic basin of the Chasqueiro Stream (Mirim Lagoon system, southern Brazil): generating subsidies for conservation and management. Biota Neotropica, Campinas, v. 15, n. 4, p. 1-13, 2015 b.

CORRÊA, F.; TUCHTENHAGEN, T.; OLIVEIRA, E. F.; POUEY, J.; PIEDRAS, S. R. N. Distribuition extension of Cyphocharax spilotus (Vari, 1987) Characiformes: Curimatidae, at Patos-Mirim lagoon system, Rio Grande do Sul State, Brazil. Pan-American Journal of Aquatic Sciences, Rio Grande, v. 9, p. 43-47, 2014.

FROESE, R. Cube law, condition factor and weight-length relationships: history, meta-analysis and recommendations. Journal Applied Ichthyology, Kiel, v. 22, p. 241-253, 2006.

GARCIA, A. M.; BEMVENUTI, M.A.; VIEIRA, J. P.; MARQUES, D. M. L. M.; BURNS, M. D. M.; MORESCO, A.; CONDINI, M. V. L. Checklist comparison and dominance patterns of the fish fauna at Taim Wetland, South Brazil. Neotropical Ichthyology, Porto Alegre, v. 4, n. 2, p. 261-268, 2006.
HAMMER, Ø.; HARPER, D. A. T.; RYAN, P. D. PAST: paleontological statistics software package for education and data analysis. 2013. Palaeontologia Electronica, PAST, 3.0. Disponível em: <http://palaeo-electronica.org/2001_1/past/past.pdf >.

HERMES-SILVA, S.; ZANIBONI-FILHO, E. Structure of the littoral fish assemblage in an impounded tributary: the effects of macrophytes presence (subtropical region, Brazil). Brazilian Journal of Biology, São Carlos, v. 72, n. 3, p. 489-495, 2012.

LE CREN, E. D. The length-weight relationship and seasonal cycle in gonadal weight and condition in the perch, Perca fluviatilus. Journal of Animal Ecology, London, v. 20, p. 201-219, 1951.

MAZZONI, R.; COSTA, L. D. S. Feeding ecology of streamdwelling fishes from a coastal stream in the southeast of Brazil. Brazilian Archives of Biology and Technology, Curitiba, v. 50, n. 4, p. 627-635, 2007.

MELLO, F. T.; VIDAL, N.; EGUREN, G.; LOUREIRO, M. Lengthweight relationships of 21 fish species from the lower section of the Santa Lucía river basin (Canelones-Montevideo, Uruguay). Journal Applied Ichthyology, Kiel, v. 25, p. 491-492, 2009.

NOVAES, J. L. C.; CARVALHO, E. D. Population structure and stock assessment of Hoplias malabaricus (Bloch, 1794) (Actinopterygii: Characiformes) caught by artisanal fisheries in the area of transition river-reservoir in Brazil. Revista de Biología Tropical, San José, v. 59, p. 71-83, 2011.

PIEDRAS, S. R. N.; SANTOS, J. D.; FERNANDES, J. M.; TAVARES, R. A.; SOUZA, D. M.; POUEY, J. L. O. F. Caracterização da atividade pesqueira na lagoa Mirim, Rio Grande do Sul - Brasil. Revista Brasileira de Agrociência, Pelotas, v. 18, p. 107-116, 2012.

REIS, R. E.; KULLANDER, S. O.; FERRARIS, C. J. Check list of the freshwater fishes of South and Central America. Porto Alegre: Edipucrs, 2003. 729 p.

SONDOTÉCNICA, S. A. Distrito de irrigação do Arroio Chasqueiro. Sumário. Estudo realizado para a SUDESUL-MI, 1976. $46 \mathrm{p}$.

THOMAZ S. M; CUNHA, E. R. The role of macrophytes in habitat structuring in aquatic ecosystems: methods of measurement, causes and consequences on animal assemblages composition and biodiversity. Acta Limnologica Brasiliensia, Botucatu, v. 22, n. 2, p. $218-236,2010$. 